\title{
IDENTIFICATION AND QUANTIFICATION OF $\beta$ - SITOSTEROL IN LEAF OF CALOTROPIS GIGANTEA AND CALOTROPIS PROCERA BY HPTLC
}

\author{
HPTLC ILE CALOTROPIS GIGANTEA VE CALOTROPIS PROCERA YAPRA ĞINDAKİ $\beta$ - \\ SITOSTEROL ÜN TANIMLANMASI VE MIKTAR TAYINİ
}

\section{Shripad BAIRAGI ${ }^{*}$ (D), Prashant GHULE ${ }^{1} \mathbb{D}$, Ritu GILHOTRA $^{2}$}

${ }^{1}$ Suresh Gyan Vihar University, Gyan Vihar School of Pharmacy, 302017, Jaipur, Rajasthan, India

${ }^{2}$ Suresh Gyan Vihar University, Principal, School of Pharmacy, 302017, Jaipur, Rajasthan, India

\begin{abstract}
Objective: The distinguishing proof and measurement of biomarker $\beta$-sitosterol present in a leaf of Calotropis procera and Calotropis gigantea belonging to family Asclepidiaceae was carried by utilizing high performance thin-layer chromatographic (HPTLC) characterization method. In the present research work the Exterinsic Standard Method is used for quantitative assessment.

Material and Method: It assures the accuracy of quantitative investigation and particularly benifit for HPTLC analysis. Aluminum-maintained silica gel 60F254 HPTLC plates of 250 um thickness was used for chromatographic analysis. Toluene: Ethyl acetate: Glacial acetic acid acidic 8:2:0.20 (v/v/v) solvent system was used as mobile phase. Anisaldehyde sulphuric acid is used for derivatisation and was evaluated at $510 \mathrm{~nm}$.

Result and Discussion: $\beta$-sitosterol quantification in foundations of plant was observed as $11.63 \mu \mathrm{g}$ and $10.23 \mu \mathrm{g}$ for Calotropi sprocera and Calotropis gigantea respectively. The appropriateness and particularity of the established techniques was demonstrated by qualitative and quantative analysis. This established method for estimation of $\beta$-sitosterol in the leaf ofCalotropis procera and Calotropis gigantea was proved to be responsive, particular and replicable.

Keywords: Calotropis procera, Calotropis gigantea, HPTLC, identification, quantification
\end{abstract} ÖZ

Amaç: Asclepidiaceae familyasına ait Calotropis procerave Calotropis gigantean yaprağında bulunan biyomarker $\beta$-sitosterol'ün ayırt edici kanıtı ve ölçümü, yüksek performansl ince tabaka kromatografik (HPTLC) karakterizasyon yöntemi kullanılarak gerçekleştirildi. Bu çalışmada, kantitatif değerlendirme için dış standart yöntemi kullanılmıştır.

\footnotetext{
Corresponding Author/SorumluYazar: Shripad Bairagi

e-mail / e-posta: ssanandss@ gmail.com, Phone / Tel.: +919604593644
} 
Gereç ve Yöntem: Yöntem, kantitatif araştırmanın doğruluğunu să̆lamaktadır ve özellikle HPTLC analizi için uygundur. Kromatografik analiz için, $250 \mu \mathrm{m}$ kalınlığında silika jel 60F254 kaplı alüminyum HPTLC plaklarl kullanıld. Mobil faz olarak; toluen: etil asetat: glasiyal asetik asit 8: 2: 0.20 (v/v/v) çözücü sistemi kullanıld. Türevlendirme için anisaldehit sülfürik asit kullanıldı ve 510 nmdalga boyunda değerlendirildi.

Sonuç ve Tartışma: Bitki yapısındaki $\beta$-sitosterol miktarının Calotropis procera ve Calotropis gigantea

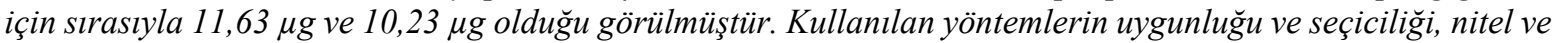
nicel analizlerle gösterilmiştir. Belirlenen bu yöntemin;Calotropis procera ve Calotropis gigantea yaprağındaki $\beta$-sitosterol miktarı tayini için, hassas, seçici ve tekrar edilebilir olduğu kanıtlanmıştır.

AnahtarKelimeler: Calotropis procera, Calotropis gigantea, HPTLC, miktar tayini, teşhis

\section{INTRODUCTION}

Estimation of plant potency was done by analyzing active components which are seen in herbals from natural origin. Legitimately established and approved technique may be utilized in qualitative as well as quantitative determination of compounds $[1,2]$.

The plant Calotropis gigantea and Calotropis Procera commonly known as Giant Milkweed, Crown Flower and Rubber Bush, Apple of Sodom respectively belongs to family Asclepidiaceae [3,4]. Calotropis procera is local to India and few Asian countries [5]. Calotropis gigantea occurs all through India from Punjab and Rajasthan in the north to Kanyakumari in the south, reaching out into West Bengal, Assam in the East [6].

The major contents present in the levaes of Calotropis Procera are amyrin, urosolicacid, calotropin, amyrin acetate,calotropagenin, $\beta$-sitosterol and cardenolides. Bioactive compounds like taraxasterylaceate, giganticine, isorhamnetin-3-O-glucopyranoside, calotroposides and isorhamnetin-3O-rutinoside were isolated from Calotropis gigantea alcoholic root extract showed different Central Nervous System properties like anxiolytic and sedative [7,8,9].

But above investigation not gives adequate knowledge to quantify the bioactive entities in the plant. [1] So, present research aimed to develop chromatographic method which can be effective in quantifying $\beta$ - sitosterol present in powderd leaf of Calotropis gigantea and Calotropis procera[10, 11, 12].

\section{MATERIAL AND METHOD}

\section{Chemicals}

Toluene, Ethyl acetate, Glacial acetic acid, $\beta$ - sitosterol and precoated Silica gel were purchased from Merck, All other reagents were analytical grade, purchased from Merck (Darmstadt, Germany). 


\section{Plant Collection and Authentication}

The leaves of both the plant Calotropis Procera and Calotropis gigantea plant was collected from nearby locality of Sonai, Ahmednagar (MH) India, and identified by the Scientist J. Jayanthi Botanical Survey of India (BSI), Pune and a voucher specimen (No. SMB 01 and No. SMB 02) was kept in the department of BSI, Pune, India.

\section{Preparation of Extract}

The leaves of Calotropis Procera and Calotropis gigantea cleaned under running water and were allowed shade dried in typical geological condition and powdered them and stored in air tight container for further use. The extraction of coarse powder was done using soxhlet apparatus by successive extraction method with different solvent respect to polarity index, [11] Solvent like Petroleum ether $\left(40-60^{\circ} \mathrm{C}\right)$, Chloroform, methanol. The marc was dried before employing the solvent of higher polarity. The obtained extracts were dried by rotary evaporator at $40-50^{\circ} \mathrm{C}$ under vacuum. Practical yield of petroleum ether extract $\left(40-60^{\circ} \mathrm{C}\right)$, chloroform extract and methanol extracts were found to be $3.82,2.34,7.04 \% \mathrm{w} / \mathrm{w}$ respectively [11].

\section{Preliminary Phytochemical Screening}

The secondary metabolites like glycosides, alkaloids, tannins, saponins, flavonoids and volatile oils are responsible for pharmacological effects. The confirmation of presence or absence of these metabolites done by chemical testslisted in table no $2[13,14]$.

\section{HPTLC Fingerprint Profiles for Various Extracts}

\section{Thin Layer Chromatography}

TLC studies were done using all the extracts for determination of phytochemicals existing in plant extracts. To conduct present research work previously coated silica gel G TLC plates were used. Activation of plate was done at $110^{\circ} \mathrm{C}$ for 30 minutes using hot air oven prior to the start of the experiment. Test extracts were applied $1 \mathrm{mg} / \mathrm{ml}$ of all extracts in the form of bands with respective solvent by Linomat 5 applicator $[15,16]$.

\section{Development of Solvent System}

To get accurate separation on plate different solvent systems were tested. We got maximum spot in methanol extract for both the plant extract. So, we took methanol extract for further experiment. Then a specific solvent system was chosen and the plates were run by a selected solvent system. After pilot level experiments it was ensured that the compounds obtained from methanol extract fraction were separated by using solvent system in a ratio of 8:2:0.2 of Toluene: Ethyl acetate: Glacial acetic acid. Anisaldehyde sulphuric acid reagent was used for derivatization of TLC plate after the development of solvent system. For detection of $\beta$ - sitosterol in UV or fluorescence light, it was therefore converted to a perceptible form to determine chromatographic estimation. 


\section{Preparation of $\beta$ - Sitosterol Standard Solutions}

\section{Composition of stock Solution (A) containing $\beta$ - Sitosterol in the concentration of $1 \mu \mathrm{g} / \mu \mathrm{l}$}

$1 \mu \mathrm{g} / \mu \mathrm{l}$ concentration of $\beta$ - sitosterol in Stock solution (A) was developed using methanol. The contents were dissolved firstly in $5.0 \mathrm{ml}$ methanol which was then sonicated and then volume was made using methanol.

\section{Composition of stock Solution (B) containing $\beta$ - Sitosterol in the concentration of $0.1 \mu \mathrm{g} / \mu \mathrm{l}$}

$0.1 \mathrm{ml}$ of stock solution A was added in a volumetric flask of $10 \mathrm{ml} .5 \mathrm{ml}$ of methanol was used to dissolve the ingredients present in the flask, which was then sonicated and finally was diluted using methanol. Hence, $0.1 \mu \mathrm{g} / \mu \mathrm{l}$ of $\beta$ - sitosterol solution was prepared for further analysis.

\section{Preparation of Sample Solution}

Due to the free solubility of $\beta$-sitosterol in methanol it was used for the extraction process. Fresh dried leaf powder $(500 \mathrm{mg})$ of Calotropis procera and Calotropis gigantea were extracted with methanol. Sonication of the mixture was done and was kept overnight to extract. The obtained filtrate after filtration of mixture from Whatman (No. 41) filter paper was used in chromatographic analysis. For quantative analysis sample solution of $10 \mu \mathrm{l}$ was compared with with standard solution.

\section{High Performance Thin Layer Chromatography}

Linomat IV applicator was used to apply the standard quantities of both the extract to previously coated plates. For HPTLC estimation standardized mobile phase of TLC was used.

\section{Chromatographic Conditions}

For effective resolution using standardized solvent system the chromatographic conditions given in table 1 were used.

\section{Preparation of Chromatogram}

The quantitative analysis was carried according to the Standard Method by application of inconsistent strength of $0.1 \mu \mathrm{g} / \mu$ lof standard $\beta$-sitosterol and the similar strength of $50 \mu \mathrm{g} / \mu \mathrm{l}$ of sample solution was applied to HPTLC plate.

\section{Standard curve of $\beta$-sitosterol}

To get an effective linearity result, reference standard $\beta$-sitosterol solution were applied in triplicate manner to a HPTLC plate at six dissimilar concentrations 5, 10, 15, 20, 25 and $30 \mu l$ containing $1,2,3,4,5$ and $6 \mu \mathrm{g}$ respectively. The resulted plate was then developed, spots derivatization, and detector response for the different strength was measured. The experiment was done in triplicate and mean values were calculated. 
Table 1. Chromatographic condition for identification and quantification.

\begin{tabular}{|l|l|}
\hline PARAMETERS & DESCRIPTION \\
\hline STATIONARY PHASE & HPTLC precoated, silica gel G 60 F254 (Merck, Germany) \\
\hline MOBILE PHASE & $8: 2: 0.2$ ration of Toluene: Ethyl acetate: Glacial acetic acid \\
\hline SIZE & $10 \times 10 \mathrm{~cm}$ \\
\hline DEVELOPING CHAMBER & Twin trough glass chamber $20 \times 10 \mathrm{~cm}$ \\
\hline MODE OF APPLICATION & Band \\
\hline BAND SIZE & $8 \mathrm{~mm}$ \\
\hline SEPARATION TECHNIQUE & Ascending \\
\hline TEMPERATURE & $6 \mathrm{O}^{\circ} \mathrm{C}$ \\
\hline SATURATION TIME & $5 \mathrm{~min}$ \\
\hline SCANNING WAVELENGTH & $510 \mathrm{~nm}$ \\
\hline SCANNING MODE & Absorbance \\
\hline
\end{tabular}

\section{RESULT AND DISCUSSION}

The quantitative assessment of $\beta$-sitosterol was conducted in the both extract using HPTLC (Figure 1). $\beta$-sitosterol is one of the common phytoconstituent therefore it is well represented in chromatogram. (Figure 1). In order to get best estimation various solvent system were used to optimize the method. From various solvent systems 8:2:0.2 ration of Toluene: Ethyl acetate: Glacial acetic acid resulted in best separation of $\beta$-sitosterol. As the $\beta$-sitosterol is not easily traceable in UV light so it transforms into the detectable substance. Derivatization was performed by immersing the TLC plate into Anisaldehyde sulphuric acid reagent for three seconds and air dried. The paltes were scanned at $510 \mathrm{~nm}$. The chromatographic conditions depicted in Table no. 1 . The $\mathrm{R}_{f}$ value (0.41) for $\beta$-sitosterol in standard (Figure 2) and sample extract (Figure $3 \& 4$ ) was found. The simple, specific and accurate HPTLC method for analysis of $\beta$-sitosterol in both the plant extract has been created.

Preliminary phytochemical screening showed the presence of different phytochemical from the leaf extract of Calotropis procera and Calotropis gigantea (Table 2).

Peak area graph and $\beta$-sitosterol concentration in root extract of Calotropis procera and Calotropis gigantea when plotted showed the linear relationship. From graph in figure 5 equation of linear regression was obtained. From the regression equation of the linear regression graph, the quantity of standard $\beta$-sitosterol applied on plate is calculated (Table 3). Similarly, the amount of $\beta$-sitosterol per $10.0 \mu \mathrm{l}$ leaf extract sample was calculated and the results are given in the Table 4 . The concentration of $\beta$-sitosterol in leaf of the plant Calotropis procera and Calotropis giganta are found to be $11.63 \mu \mathrm{g}$ and $10.23 \mu \mathrm{g}$ respectively. The employed method showed good peak shape of $\beta$-sitosterol. There was no impedance from different constituents from the extract. 


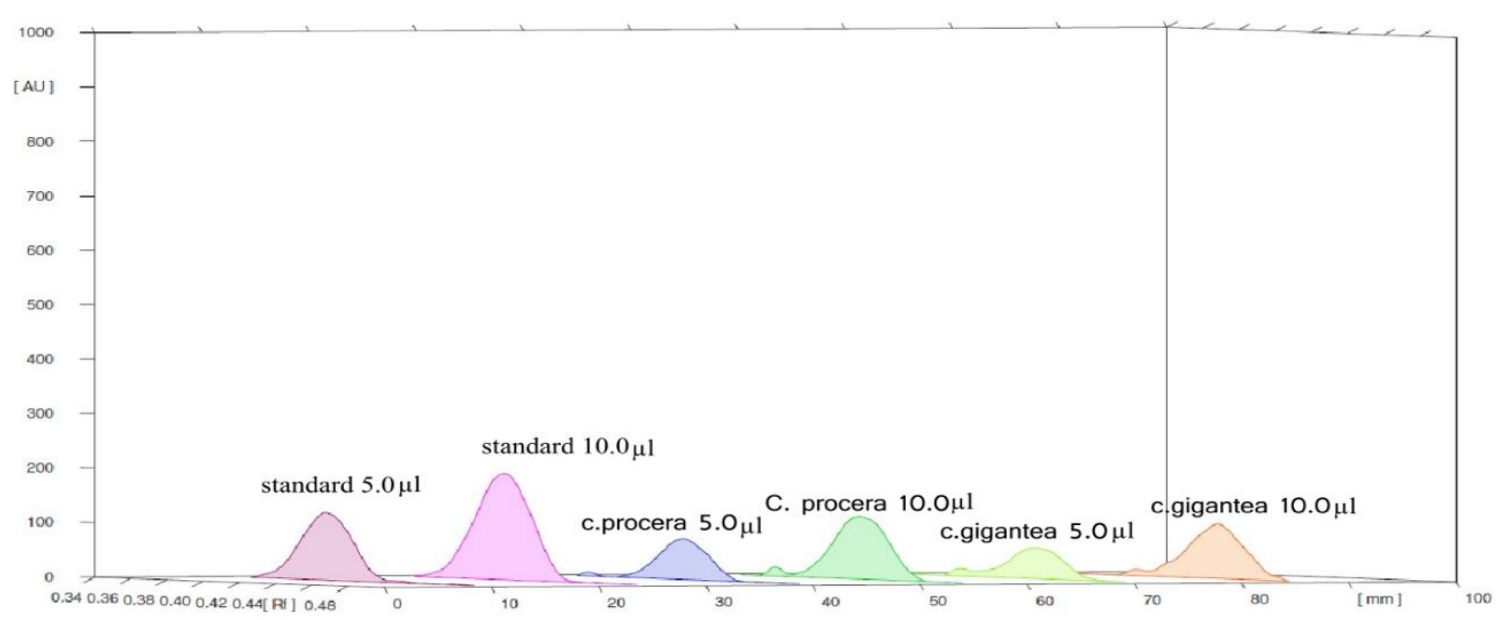

Figure 1. Destinograms of $\beta$ - sitosterol and leaf extract of Calotropis procera and Calotropis gigantea

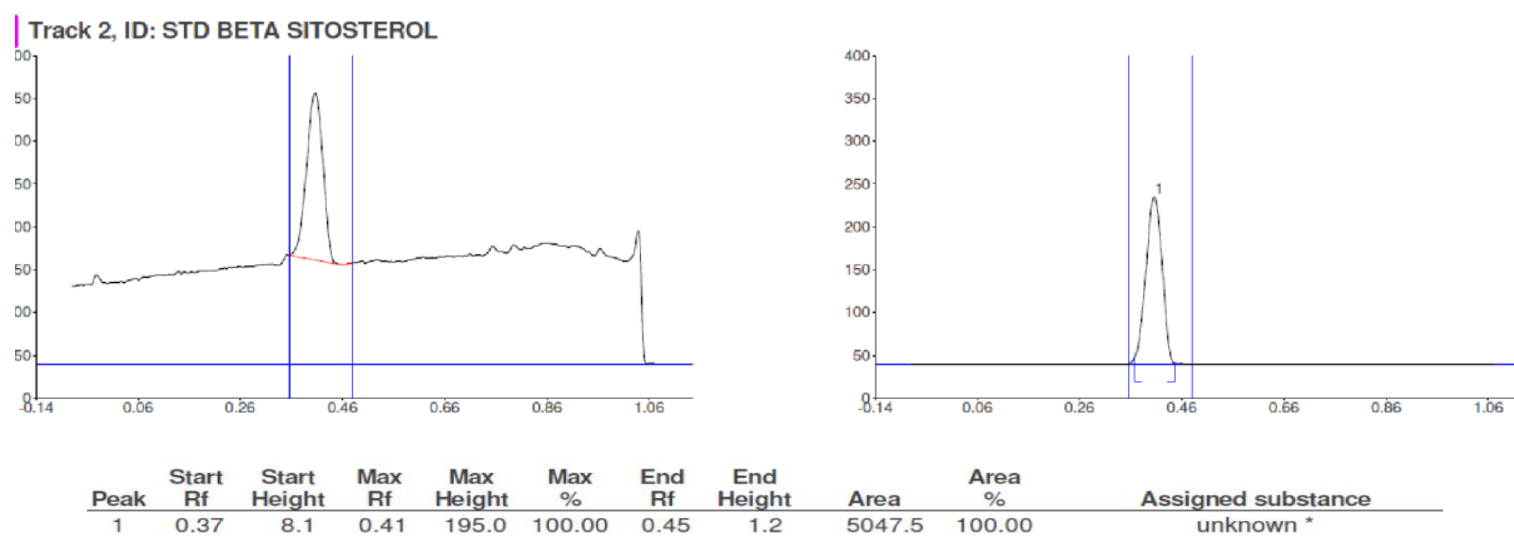

Figure 2. Chromatogram of standard $\beta$ - sitosterol

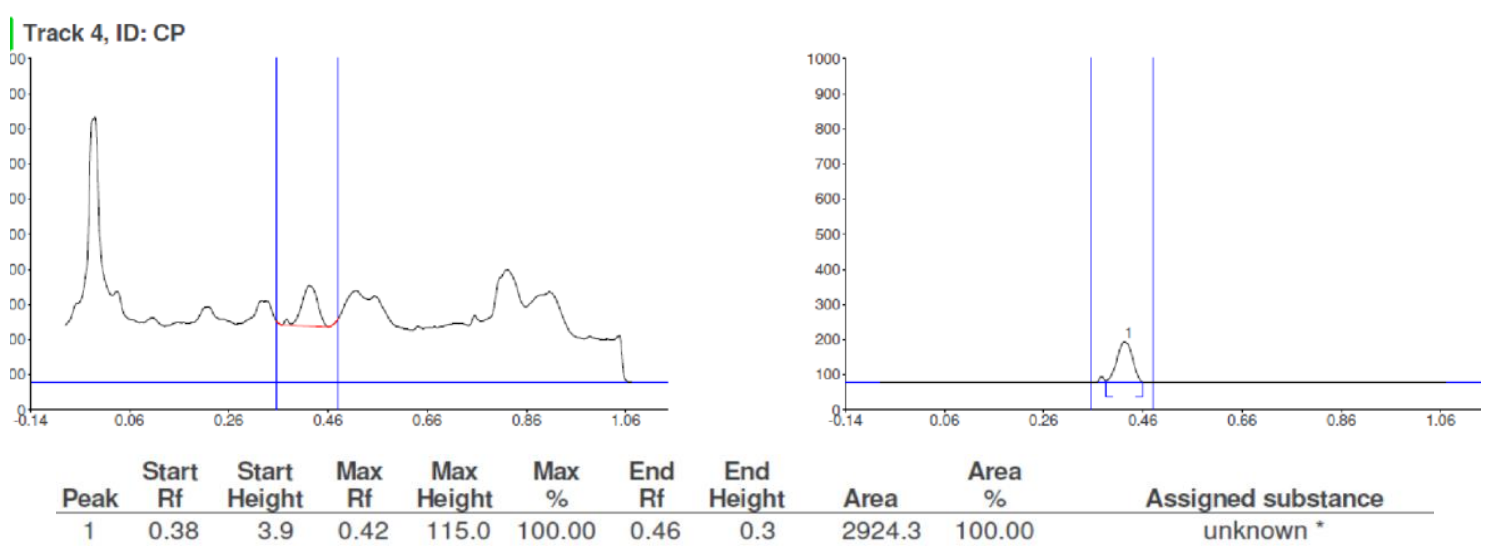

Figure 3. Chromatogram of leaf extract of Calotropis procera 


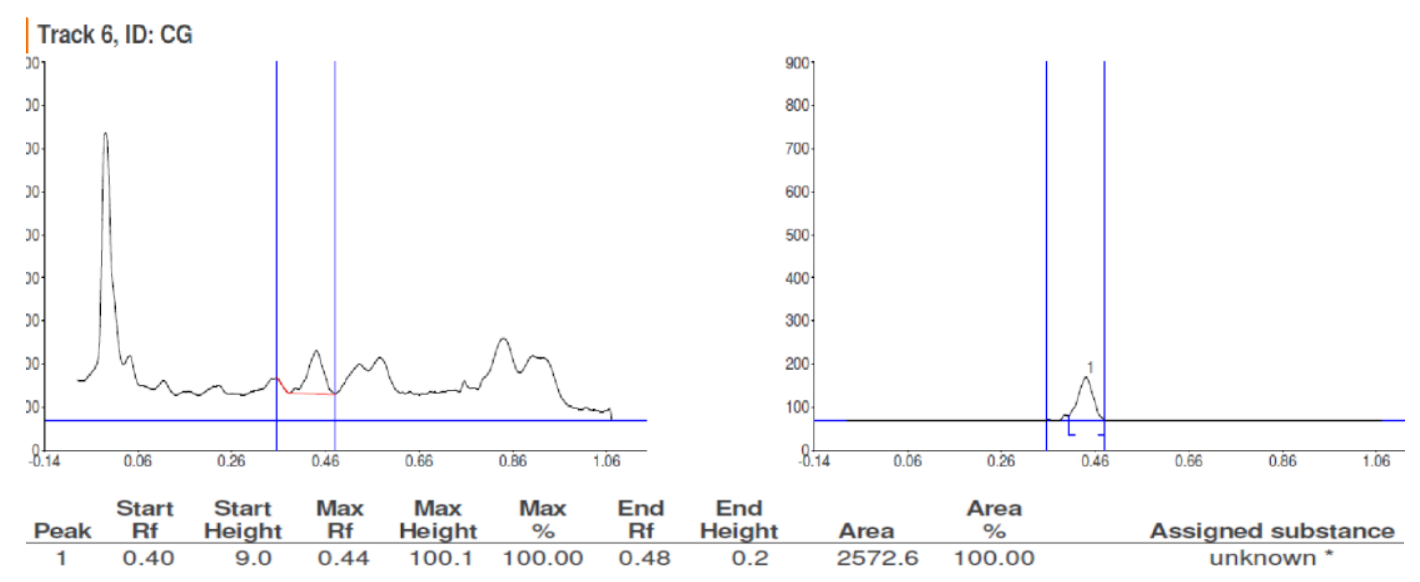

Figure 4. Chromatogram of leaf extract of Calotropis gigantea

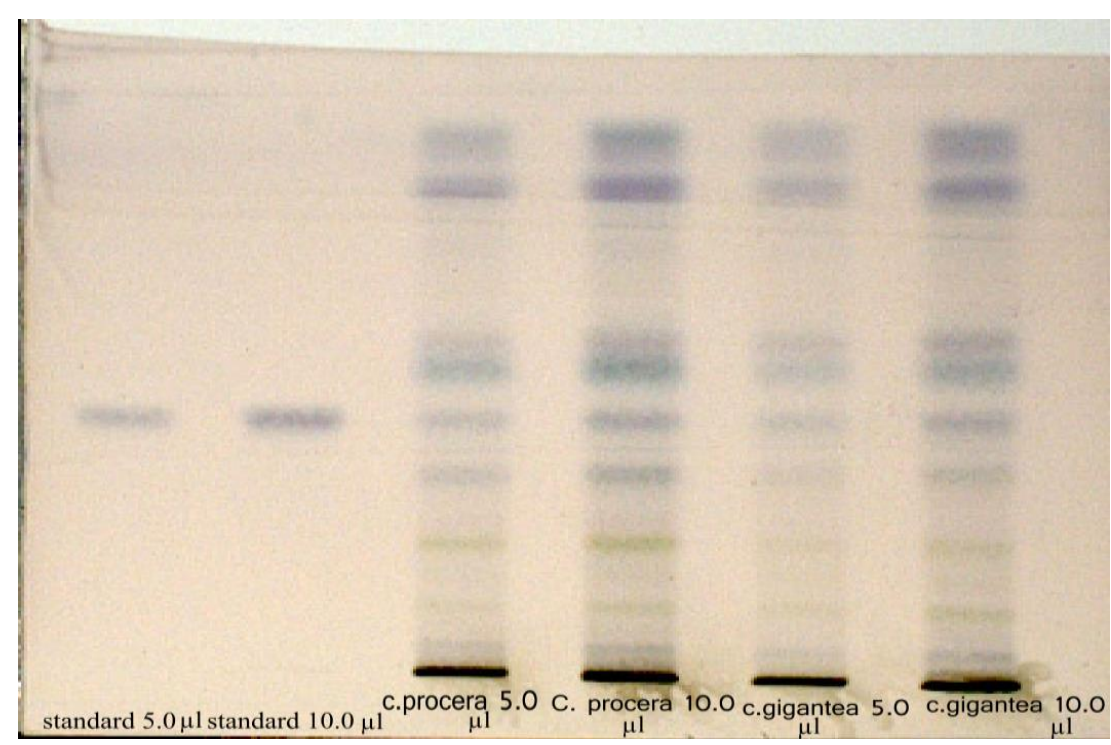

Figure 5. Quantification data of $\beta$-sitosterol in leaf extract of Calotropis procera and Calotropis gigantea by HPTLC

Though there are magnificent developments in advance medicines, traditional medicines have always been proficient for dealing with several complications. Traditional medicines are an important resource in health care across the country [17]. Herbals are usually obtained from the mixture and its potency depends on the presence of the phytoconstituents [18]. Accuracy in quantitative and qualitative estimation is an important and essential necessity to make sure reproducible quality of natural source medicines. Assessment of phytochemicals shows the quality measurement, including preliminary testing to detection of active compound analysis, using modern analytical methods. HPTLC has proven effective method for the estimation of phytochemicals from natural origin [19]. 
The present study was aimed to quantify $\beta$-sitosterol form the extracts of Calotropis procrea and Calotropis gigantea. Research has shown that Calotropis procrea and Calotropis gigantea executed various medicinal properties [6]. In present research quantitative estimation of $\beta$-sitosterol was conducted using HPTLC. The $\mathrm{R}_{f}$ value (0.41) of $\beta$-sitosterol in standard and both the extract was found comparable at $510 \mathrm{~nm}$ under the UV light. HPTLC study was carried out to confirm the presence of $\beta$ sitosterol $\left(\mathrm{R}_{f}\right.$ value 0.41$)$ using 8:2:0.2 ratio of Toluene: Ethyl acetate: Glacial acetic acid as a solvent system. The selection of accurate mobile phase and sample preparation are the most crucial steps in analytical work, therefore in present study the development of the preparation of sample and selection of mobile phase were optimized. TLC and HPTLC techniques are the benchmark in the qualitative determination of the fractional amount of substances. This analytical method was established as easy, dependable and appropriate for qualitative estimation. From the present findings it confirms that the $\beta$ sitosterol can be reliably and conveniently estimated by HPTLC method for standardization purposes.

Table 2. Preliminary phytochemical screening of leaf extract of $C$. procera and C. gigantea

\begin{tabular}{|c|l|l|l|}
\hline SR.NO. & $\begin{array}{l}\text { PHYTOCHEMICAL } \\
\text { CATEGORY }\end{array}$ & C. PROCERA & C.GIGANTEA \\
\hline $\mathbf{1}$ & Carbohydrate & Present & absent \\
\hline $\mathbf{2}$ & Alkaloids & Present & Present \\
\hline $\mathbf{3}$ & Cardiac Glycosides & Present & Present \\
\hline $\mathbf{4}$ & Anthraquinone glycosides & Present & Present \\
\hline $\mathbf{5}$ & Terpenoids & Present & Present \\
\hline $\mathbf{6}$ & Fats and Oils & Absent & Absent \\
\hline $\mathbf{7}$ & Flavanoids & Present & Present \\
\hline $\mathbf{8}$ & Saponin & Present & absent \\
\hline $\mathbf{9}$ & Tannin and phenolic comp. & Present & Present \\
\hline $\mathbf{1 0}$ & Steroids \& Sterol & Present & Present \\
\hline $\mathbf{1 1}$ & Protein and Amino acid & Absent & Present \\
\hline
\end{tabular}

Table 3. The $\mathrm{R}_{\mathrm{f}}$ values and Peak Areas of standard compound- $\beta$-sitosterol and leaf extract of C. procera and C. gigantea

\begin{tabular}{|c|l|l|l|l|l|}
\hline SR.NO. & APPLIED SAMPLE & $\begin{array}{l}\text { APPLIED } \\
\text { POSITION }\end{array}$ & APPLIED VOL & RF VALUE & PEAK AREA \\
\hline $\mathbf{1}$ & Standard $\beta$-sitosterol & $12.0 \mathrm{~mm}$ & $5.0 \mu \mathrm{l}$ & 0.41 & 5047.5 \\
\hline $\mathbf{2}$ & Standard $\beta$-sitosterol & $27.2 \mathrm{~mm}$ & $10.0 \mu \mathrm{l}$ & 0.41 & 10094 \\
\hline $\mathbf{3}$ & Calotropis procera & $42.4 \mathrm{~mm}$ & $5.0 \mu \mathrm{l}$ & 0.42 & 2924.3 \\
\hline $\mathbf{4}$ & Calotropis procera & $57.6 \mathrm{~mm}$ & $10.0 \mu \mathrm{l}$ & 0.42 & 5845.6 \\
\hline $\mathbf{5}$ & Calotropis gigantea & $72.8 \mathrm{~mm}$ & $5.0 \mu \mathrm{l}$ & 0.44 & 2572.6 \\
\hline $\mathbf{6}$ & Calotropis gigantea & $88.0 \mathrm{~mm}$ & $10.0 \mu \mathrm{l}$ & 0.44 & 5145.2 \\
\hline
\end{tabular}

Table 4. The amount of $\beta$-sitosterol

\begin{tabular}{|c|l|l|l|l|l|}
\hline SR.NO. & APPLIED SAMPLE & APPL. VOL. & RF & PEAK AREA & AMOUNT OF $\beta$-SITOSTEROL \\
\hline $\mathbf{1}$ & Calotropis procera & $5.0 \mu \mathrm{l}$ & 0.42 & 2924.3 & $5.8 \mu \mathrm{g}$ \\
\hline $\mathbf{2}$ & Calotropis procera & $10.0 \mu \mathrm{l}$ & 0.42 & 5845.6 & $11.63 \mu \mathrm{g}$ \\
\hline $\mathbf{3}$ & Calotropis gigantea & $5.0 \mu \mathrm{l}$ & 0.44 & 2572.6 & $5.10 \mu \mathrm{g}$ \\
\hline $\mathbf{4}$ & Calotropis gigantea & $10.0 \mu \mathrm{l}$ & 0.44 & 5145.2 & $10.23 \mu \mathrm{g}$ \\
\hline
\end{tabular}


HPTLC estimation was done for quantification of $\beta$-sitosterol from extract of leaf from Calotropis procera and Calotropis gigantea. As a wide application of $\beta$-sitosterol in herbal medicines the HPTLC analysis technique ensures the specification and characteristics of medicinal plants. The method used by Niyati et al for quantification and identification of plant extract of $\beta$-sitosterol by HPTLC, accuracy of identification was less by using the Tolune:Methaol(9.4:0.6) solvent system, current research focuses on newly developed Toluene: Ethyl acetate: Glacial acetic acid(8:2:0.2) solvent system for HPTLC quantification and identification $\beta$-sitosterol with more accuracy and precision (Fig no. $1 \& 5$ ) [20].This established method for estimation of $\beta$-sitosterol in the leaf of Calotropis procera and Calotropis gigantea was proved to be responsive, perticular and replicable.

\section{AUTHOR CONTRIBUTIONS}

Conception: S.B., P.G., R.G.; Design: S.B., P.G.; Supervision: S.B., P.G., R.G.; Resources: S.B., P.G.; Materials: S.B.; Data collection and/or processing: S.B.; Analysis and/or interpretation: S.B., P.G., R.G.; Literature search: S.B.; Writing manuscript: S.B.; Critical review: S.B., P.G., R.G.; Other: -

\section{CONFLICT OF INTEREST}

The authors declare no conflict of interest.

\section{REFERENCES}

1. Aparna, S., Aruna, S. (2015). HPTLC Method for Identification and Quantification of $\beta$ sitosterol in the Roots of Achyranthesaspera Linn. International Journal of Pharmaceutical Science, 5(4), 1117-1122. https//doi.org/10.7598/cst2015.1137

2. Midmore, D.J. (2017). Principles of tropical horticulture. The Future of Tropical Horticulture, (pp. 353-418). Oxfordshire, UK. https://doi.org/10.1079/9781780645414.035

3. Khairnar, A.K., Bhamare, S.R., Bhamare, H.P. (2012). Calotropis procera: An ethnopharmacological update. Advance Research in Pharmaceuticals and Biologicals, 2(2), 142-156. https://doi.org/10.22159/ajpcr.2017.v10i11.21215

4. Rahman, M., Wilcock, C. (1991). A taxonomic revision of Calotropis (Asclepiadaceae). Nordic Journal of Botany, 11(3), 301-308. http://dx.doi.org/10.1111/j.1756-1051.1991.tb01408.x

5. Chatterjee, A., Chandra, P.S. (1995). The Treatise of Indian Medicinal Plants: Volume: IV. Nat Inst of Sc Communication, New Delhi, India.

6. Shripad, M.B., Prashant, G.J., Gilhotra, R. (2018). Pharmacology of Natural Products: A recent approach on Calotropis gigantea and Calotropis procera. ArsPharmaceutica, 59(1), 37-44. http://dx.doi.org/10.4321/S2340-98942018000100004 
7. Palejkar, C.J., Palejkar, J.H., Patel, M.A., Patel, A.J. (2012). A comprehensive review on plant Calotropis gigantea. International Journal of Institutional Pharmacy and Life Sciences, 2(2), 463-470.

8. Abhishek, D., Mohit, C., Ashish, G., Ameeta, A. (2010). Medicinal utility of Calotropis procera (Ait.) R. Br. as used by natives of village Sanwer of Indore District, Madhya Pradesh. International Journal of Pharmacy \& Life Sciences, 1(3), 188-190. http://dx.doi.org/10.18203/2319-2003.ijbcp20161484

9. Al-Snafi, A.E. (2015). The constituents and pharmacological properties of Calotropis proceraan overview. International Journal of Pharmacy Review and Research, 5(3), 259-275.

10. Kitagawa, I., Zhang, R.S., Park, J.D., Baek, N.I, Takeda, Y., Yoshikawa, N., Shibuya, H. (1992). Indonesian plants, I. chemical structures of calotroposides A and B two new oxypreganeoligoglycosides from the root of Calotropis gigantea (Asclepiadaceae). Chemical and Pharmaceutical Bulletin, 140, 2007-2013. https://doi.org/10.1248/cpb.31.689

11. Pari, K., Rao, P.J., Devakumar, C., Rstogi, J.N. (1998). A novel insect antifeedantnonprotein amino acid from Calotropicsgigantean. Journal of Natural Product, 61, 102-104. doi: $10.1021 / \mathrm{np} 970255 \mathrm{z}$.

12. Sen, S., Sahu, N.P., Mahato, S.B. (1992). Flavonol glycosides from Calotropicsgigantean. Phytochemistry, 31, 2919-2921. doi: 10.1016/0031-9422(92)83668-o.

13. Khandelwal, K. (2008). Practical Pharmacognosy, Techniques and Experiments, Nirali Prakashan, India, p.320.

14. Mukherjee, P.K. (2002). Quality Control of Herbal Drugs- An Approach to Evaluation of Botanicals, Business Horizons, p.800.

15. Shah, S.A., Ravishankara, M.N., Nirmal, A., Shishoo, C.J., Rathod, I.S., Suhagia, B.N. (2000). Estimation of individual sennosides in plant materials and marketed formulations by HPTLC method. Journal of Pharmacy and Pharmacology, 52, 445-449. https://doi.org/10.1211/0022357001774066

16. Stahl, E. (1969). Thin Layer Chromatography-A Laboratory Handbook, Springer-Verlag Berlin Heidelberg, p.1041. https://www.springer.com/gp/book/9783642884900

17. Shaikh, B.T., Hatcher, J. (2005). Complementary and alternative medicine in Pakistan: prospects and limitations. Evidence Based Complementary and Alternative Medicine, 2(2), 139142. https://doi.org/10.1093/ecam/neh088

18. Kunle, O.F., Egharevba, H.O., Ahmedu, P.O. (2012). Standardization of herbal medicines-A review. International Journal of Biodiversity and Conservation, 4(3), 101-112. https://doi.org/10.5897/IJBC11.163

19. Chawla, R., Thakur, P., Chowdhry, A., Jaiswal, S., Sharma, A., Goel, R., Sharma, J., Priyadarshi, S.S., Kumar, V., Sharma, R.K., Arora, R. (2013). Evidence based herbal drug standardization approach in coping with challenges of holistic management of diabetes: a dreadful lifestyle disorder of 21st century. Journal of Diabetes and Metabolic Disorders, 12(1), 35. https://doi.org/10.1186/2251-6581-12-35 
20. Niyati, S.A., Sanjeev, R.A., Mamta, B.S., Dev, D.S. (2012). Development of pharmacognostical parameters and estimation of $\beta$-sitosterol using HPTLC in roots of Gmelina arborea Roxb. Pharmacognosy Journal, 30(4), 1-9. 